\title{
Pengaruh Gaya Kepemimpinan Demokratis dan Iklim Kerja Terhadap Semangat Kerja Karyawan Pada PT. Sumatera Hakarindo Palembang
}

\author{
Jaka Saputra ${ }^{1}$, Suhada ${ }^{2}$ \\ ${ }^{1}$ Manajemen, Fakultas Ekonomi Universitas PGRI Palembang \\ 2Manajemen, FE Universitas PGRI Palembang, suhada@univpgri-palembang.ac.id
}

\begin{abstract}
ABSTRAK
Penelitian ini bertujuan untuk mengetahui pengaruh gaya kepemimpinan demokratis dan iklim kerja terhadap semangat kerja karyawan pada PT. Sumatera Hakarindo Palembang. Metode penelitian yang digunakan adalah deskriptif kuantitatif. Populasi penelitian karyawan tetap PT. Sumatera Hakarindo Palembang berjumlah 40 orang. Teknik pengambilan sampel adalah sensus sehingga jumlah sampel adalah 40 responden. Skala pengukuran adalah skala Likert. Teknik ujicoba instrumen adalah uji validitas dan reliabilitas. Data yang digunakan adalah data primer dengan teknik pengumpulan data yaitu observasi, wawancara dan kuisoner. Teknik analisis data adalah regresi linier berganda yang didahului uji asumsi klasik, koefisien deminasi, uji $F$ dan uji t. Penelitian ini menghasilkan secara simultan, gaya kepemimpinan demokratis dan iklim kerja berpengaruh signifikan terhadap semangat kerja karyawan pada PT. Sumatera Hakarindo Palembang, secara parsial, gaya kepemimpinan demokratis berpengaruh signifikan terhadap semangat kerja karyawan pada PT. Sumatera Hakarindo Palembang dan secara parsial, iklim kerja berpengaruh signifikan terhadap semangat kerja karyawan pada PT. Sumatera Hakarindo Palembang.
\end{abstract}

Kata kunci : Gaya Kepemimpinan Demokratis, Iklim Kerja, Semangat Kerja

\begin{abstract}
This study aims to determine the effect of democratic leadership style and work climate on employee morale at PT. Sumatra Hakarindo Palembang. The research method used is descriptive quantitative. The research population of permanent employees of PT. Sumatra Hakarindo Palembang numbered 40 people. The sampling technique is census so that the number of samples is 40 respondents. The measurement scale is a Likert scale. The instrument testing technique is a test of validity and reliability. The data used are primary data with data collection techniques namely observation, interviews and questionnaires. The data analysis technique is multiple linear regression which is preceded by the classical assumption test, the coefficient of demination, the $F$ test and the $t$ test. This research resulted simultaneously, democratic leadership style and work climate significantly influence employee morale at PT. Sumatera Hakarindo Palembang, partially, democratic leadership style significantly influences employee morale at PT. Sumatera Hakarindo Palembang and partially, the work climate has a significant effect on employee morale at PT. Sumatra Hakarindo Palembang.
\end{abstract}

Keywords: Democratic Leadership Style, Work Climate, Work Spirit

\section{A. PENDAHULUAN}

Kemajuan suatu organisasi baik instansi pemerintah maupun perusahaan tergantung pada sumber daya manusia yang mengelolanya sehingga semangat kerja pegawai atau karyawan perlu selalu dipertahankan bahkan ditingkatkan. Sumber daya manusia sebagai salah satu penentu keberhasilan perusahaan maka sumber daya manusia menjadi aset organisasi yang berperan penting dalam menjalankan aktivitas organisasi. .

Sumber daya manusia yang paling berpengaruh dalam memelihara 
semangat kerja pegawai dan karyawan adalah para pemimpin organisasi. Untuk itu, diperlukan pemimpin yang dapat mengarahkan dan mengembangkan potensi bawahan sesuai dengan sasaran organisasi atau perusahan. Sasaran tersebut dapat terwujud jika orang-orang yang berada di dalamnya mampu bekerja sama dan berkoordinasi dan pemimpin memiliki kemampuan untuk mengarahkan anggotanya.

Salah satu perusahaan di Kota Palembang yang bergerak di bidang penyediaan kemasan dengan memproduksi kotak karton yaitu PT. Sumatera Hakarindo Palembang juga memiliki sasaran berupa target pencapaian jumlah produksi yang telah ditetapkan. Target ini merupakan wahana untuk mencapai visi perusahaan yaitu menjadi pengembang dan pengelola kawasan industri dan bisnis yang andal dan modern. Yang dimaksud andal dan modern adalah 1)produk yang di hasilkan memenuhi syarat kebutuhan investor, baik dipandang dari sisi kualitas, kuantitas maupun estetika 2)fasilitas dan layanan yang di sediakan lengkap di kawasan industry dan 3)pelayanan kepada pelanggan memuaskan dengan survey kepuasan dan ketidakpuasan pelanggan

Pencapaian target tersebut membutuhkan semangat kerja dari karyawannya. Semangat kerja dapat diartikan sebagai suatu kondisi rohaniah atau perilaku individu tenaga kerja dan kelompok-kelompok yang dapat menimbulkan kesenangan yang mendalam pada diri sendiri tenaga kerja untuk berkerja giat dan konsekuen dalam mencapai tujuan yang telah ditetapkan perusahaan. Busro (2018:326)menjelaskan semangat kerja membutuhkan peran serta pemimpin dalam memotivasi karyawan dan iklim kerja yang mendukung pelaksanaan pekerjaan karyawan.

Kepemimpinan merupakan upaya mempengaruhi banyak orang melalui komunikasi untuk mencapai tujuan. Caranya, dengan mempengaruhi orang dengan petunjuk atau perintah dan tindakan yang menyebabkan orang lain bertindak atau merespon sehingga perubahan yang positif, membangkitkan kekuatan dinamis penting yang dapat memotivasi dan mengoordinasikan organisasi dalam rangka mencapai tujuan (Busro, 2018:216).

Wawancara terhadap 40 orang karyawan tetap PT. Sumatera Hakarindo mengenai gaya kepemimpinan yang dilaksanakan di PT. Sumatera Hakarindo. Rekapitulasi persetujuan terhadap gaya kepemimpinan yang dilaksanakan di PT. Sumatera Hakarindo adalah 57\% (23 orang) menyatakan setuju bahwa pimpinan melaksanakan gaya kepemimpinan demokratis, $21 \%$ (9 orang) setuju bahwa pimpinan melaksanakan gaya kepemimpinan otokratis dan $14 \%$ (6 orang) setuju bahwa pimpinan melaksnakan gaya kepemimpinan kharismatik. Berdasarkan hasil wawancara tersebut maka ditetapkan salah satu variabel yang akan diteliti adalah gaya kepemimpinan demokratis yang ada di PT. Sumatera Hakarindo Palembang. Thoha (2010:42) menjelaskan kepemimpinan demokratis merupakan pemimpin yang selalu berusaha meminta dan mengunakan saransaran dari bawahannya.

Pencapaian tujuan dalam suatu organisasi oleh anggota organisasinya membutuhkan ketenangan, kenyamanan serta keamanan dalam melaksanakan tugas di lingkungan organisasi. Suatu organisasi dapat berjalan dengan baik apabila orangorang yang berkumpul dalam 
organisasi tersebut dapat melaksanakan tugas dan fungsinya dengan baik, serta di tunjang oleh situasi dan kondisi yang baik pada organisasi itu sendiri, yang sering di sebut iklim kerja.

Dengan iklim kerja yang baik, maka setiap pegawai dapat menyelesaikan segala beban perusahaan dengan efektif dan efisien sehingga masalah yang terjadi pada perusahaan dapat teratasi dengan baik. Berdasarkan observasi dan wawancara yang dilakukan pada PT. Sumatera Hakarindo Palembang, masih terjadi iklim kerja yang kurang baik bagi pegawai seperti kurangnya sikap kebersamaan, dan kurangnya sikap kerja sama sehingga mempengaruhi optimalisasi penyelesaian pekerjaan.

Uraian mengenai semangat kerja karyawan, gaya kepemimpinan dan iklim kerja pada PT. Sumatera Hakarindo Palembang memberikan latar belakang terhadap tujuan penelitian ini. Tujuan penelitian ini adalah : 1)untuk mengetahui pengaruh gaya kepemimpinan demokratis dan iklim kerja terhadap semangat kerja karyawan pada PT. Sumatera Hakarindo Palembang 2)untuk mengetahui pengaruh gaya kepemimpinan demokratis terhadap semangat kerja karyawan pada PT. Sumatera Hakarindo Palembang dan 3)untuk mengetahui gaya kepemimpinan demokratis dan iklim kerja secara bersama-sama terhadap semangat kerja karyawan pada PT. Sumatera Hakarindo Palembang.

\section{B. KAJIAN TEORI}

\section{Gaya Kepemimpinan Demokratis}

Rivai dan Mulyadi (2011:42) menjelaskan gaya kepemimpinan adalah pola menyeluruh dari tindakan seseorang pemimpin, baik yang tampak maupun yang tidak tampak oleh bawahnya. Gaya kepemimpinan mengambarkan kombinasi yang konsisten dari falsafah, keterampilan, sifat, dan sikap yang mendasari prilaku seseorang.

Senang dan Maslachah (2018:42) menjelaskan kepemimpinan demokratis dikaitkan dengan kekuatan personal dan keikutan serta para pengikut dalam proses pemecahan masalah dan pengambilan keputusan. Senang dan Maslachah (2018:43) juga menjelaskan cirri-ciri pemimpin demokratis yaitu 1)beban kerja organisasi menjadi tanggung jawab bersama personalia organisasi itu 2)bawahan, oleh pemimpin dianggap sebagai komponen pelaksanaan secara integral harus diberi tugas dan tanggung jawab 3)disiplin akan tetapi tidak kaku dan memecahkan masalah secara bersama 4)kepercayaan tinggi terhadap bawahan dengan tidak melepaskan tanggung jawab pengawasan dan 5)komunikasi dengan bawahan bersifat terbuka dan dua arah.

Indikator kepemimpinan menurut Sedarmayanti (2011:64) adalah 1)berkomunikasi 2)mengkoordinasikan 3)mengorganisasikan 4)memotivasi 5)memanfaaatkan sumber daya 6)meningkatkan keterampilan bawahan dan menjamin setiap orang memperoleh informasi yang jelas dan benar dan 7)mengkliasifikasi harapan dari organisasi dan menjelaskan metode apa yang akan digunakan untuk mencapai harapan.

\section{Iklim Kerja}

Handoko dalam Suryalena dan Multi (2013:29) menjelaskan ikim kerja yaitu lingkungan manusia di mana para karyawan organisasi melaksanakan pekerjaan mereka. Iklim tidak dapat dilihat dan disentuh tetapi iklim tersebut ada dan akan mempengaruhi segala sesuatu yang terjadi dalam 
organisasi.

Dimensi-dimensi pengukuran iklim kerja menurut Rahsel (2016:110) adalah 1)kompromi, kondisi organisasi yang memberikan keleluasaan bertindak bagi karyawan serta melakukan penyesuaian diri terhadap tugas-tugas yang diberikan 2)tanggung jawab, berkaitan dengan perasaan karyawan mengenai pelaksanaan tugas organisasi yang diemban dengan rasa tanggung jawab atas hasil yang dicapai karena mereka terlibat didalam proses yang sedang berjalan 3)penghargaan, berkaitan dengan perasaan karyawan tentang penghargaan dan pengakuan atas pekerjaan yang baik 4)kejelasan, terkait dengan perasaan pegawai bahwa mereka mengetahui apa yang diharapkan dari mereka sesuai dengan pekerjaan, peranan dan tujuan organisasi 5)komitmen tim, berkaitan dengan perasaan karyawan mengenai perasaan bangga mereka memiliki organisasi dan kesediaan untuk berusaha lebih saat dibutuhkan.

Indikator iklim kerja menurut Hasibuan dalam Suryalena dan Multi (2013:31) adalah 1)lingkungan pekerjaan, segala sesuatu yang ada di sekitar pekerja dan yang dibebankan dengan faktor-faktor yang harus diperhatikan guna mendukung suasana lingkungan kerja yaitu penerangan atau cahaya dan pertukaran udara 2)keamanan 3)hubungan sesama anggota organisasi 4)kepemimpinan dalam organisasi.

\section{Semangat Kerja}

Siswanto dalam Busro (2018:326) mendefinisikan semangat kerja sebagai diartikan sebagai kondisi rohaniah atau perilaku individu tenaga kerja dan kelompok kelompok yang dapat menimbulkan kesenangan yang mendalam pada diri tenaga kerja untuk bekerja dengan giat dan konsekuen dalam mencapai tujuan yang telah ditetapkan perusahaan. Faktor-Faktor yang mempengaruhi semangat kerja menurut Anoraga dalam Busro (2018:327) adalah 1)keamanan kerja, pekerjaan yang dipegang karyawan tersebut merupakan pekerjaan yang relatif tetap 2)kesempatan untuk mendapat kemajuan, karyawan dapat mengembangkan diri atau karirnya 3)kondisi kerja yang menyenangkan, lingkungan kerja yang harmonis 4)kepemimpinan yang baik, tidak menimbulkan rasa takut pada karyawan dan akan menimbulkan rasa hormat karyawan dan 5)kompensasi gaji imbalan, semakin tinggi pendapatan yang diterima semakin tinggi pula semangat kerjanya dan sebaliknya.

Tujuan dilakukannya penilaian semangat kerja pegawai menurut Busro (2018:337), yaitu untuk 1)mengetahui tingkat semangat kerja pegawai selama ini 2)membuat dasar pemberian imbalan yang serasi 3)membedakan semangat kerja antara pegawai satu dengan yang lain 4)mengembangkan sumber daya manusia untuk penugasan kembali, promosi/kenaikan

5)meningkatkan motivasi kerja 6)meningkatkan etos kerja 7)memperkuat hubungan antara pegawai dan 8)membuat kriteria keberhasilan pegawai.

Busro (2018:330) menjelaskan indikator yang dapat mengukur semangat kerja yaitu 1)absensi, menunjukan ketidakhadiran karyawan dalam tugasnya 2)kerja sama, semakin tinggi intensitas kerja sama karyawan dengan karyawan lain menujukan semakin tinggi semangat kerja karyawan tersebut 3)kepuasan kerja, semakin tinggi tingkat kepuasan kerja seseorang, dapat dikatakan semakin tinggi semangat kerja karyawan tersebut 4)kedisiplinan, suatu sikap 
dan tingkah laku yang sesuai peraturan organisasi dalam bentuk tertulis maupun tidak dan 5)kegairahan kerja, kegairahan kerja diperlihatkan oleh pegawai dalam melakukan pekerjaan atau kesenangan yang mendalam melaksanakan pekerjaan.

\section{Hipotesis Penelitian}

Hipotesis yang diusulkan dalam penelitian ini adalah 1)Hipotesis 1 : secara simultan, gaya kepemimpinan demokratis dan iklim kerja berpengaruh signifikan terhadap semangat kerja karyawan pada PT. Sumatera Hakarindo Palembang 2) Hipotesis 2 : secara parsial, gaya kepemimpinan demokratis berpengaruh signifikan terhadap semangat kerja karyawan pada PT. Sumatera Hakarindo Palembang 3)Hipotesis 3 : secara parsial, iklim kerja berpengaruh signifikan terhadap semangat kerja karyawan pada PT. Sumatera Hakarindo Palembang

\section{PROSEDUR PENELITIAN Metode Penelitian}

Metode yang digunakan dalam penelitian ini adalah metode kuantitatif karena data penelitian berupa angka dengan analisis data bersifat statistik.

\section{Variabel Penelitian}

Variabel dalam penelitian ini terdiri dari variabel bebas (independen) yang disebut dengan variabel $X$, merupakan variabel yang tidak tergantung dengan variabel lainnya. Variabel $X$ dalam penelitian ini adalah gaya kepemimpinan demokratis $\left(X_{1}\right)$, iklim kerja $\left(X_{2}\right)$ dan variabel terikat (dependen) yang disebut dengan variabel $\mathrm{Y}$, merupakan variabel yang tergantung atau terpengaruh oleh variabel lainnya. Variabel $(Y)$ dalam penelitian ini adalah semangat kerja.

\section{Definisi Operasionalisasi Variabel}

Definisi operasionalisasi variabel dalam penelitian ini adalah 1)gaya kepemimpinan demokratis, dikaitkan dengan kekuatan personal dan keikutan serta para pengikut dalam proses pemecahan masalah dan pengambilan keputusan (Senang dan Maslachah, 2018:42) 2)iklim kerja, yaitu lingkungan manusia di mana para karyawan organisasi melaksanakan pekerjaan mereka. Iklim kerja tidak dapat dilihat dan di sentuh tetapi iklim kerja tersebut ada dan akan mempengaruhi segala sesuatu yang terjadi dalam organisasi (Handoko dalam Suryalena dan Multi, 2013:29) dan 3)semangat kerja, yaitu suasana batin untuk melakukan pekerjaan secara lebih giat sehingga pekerjaan cepat selesai dan lebih baik serta ongkos per unit dapat diperkecil (Anoraga dalam Busro, 2018:326 ).

$$
\text { Indikator variabel gaya }
$$

kepemimpinan demokratis adalah
1)watak
2) visi
3)kemampuan

4)memberi motivasi 5)memberi arahan dan 6)melaksanakan evaluasi (Rivai dan Mulyadi, 2011:105). Indikator variabel iklim kerja yaitu 1)lingkungan pekerjaan 2)keamanan )hubungan sesama anggota organisasi dan 4)kepemimpinan (Hasibuan dalam Suryalena dan Multi, 2013:31). Indikator variabel semangat kerja yaitu 1)absensi 2)kerja sama 3)kepuasan kerja 4)kedisiplinan dan 5)kegairahan kerja (Busro, 2018:330).

\section{Skala Pengukuran}

Skala pengukuran digunakan dengan tujuan agar nilai variabel yang diukur dengan instrumen tertentu dapat dinyatakan dalam bentuk angka sehingga lebih akurat, efisien dan komunikatif. Jawaban responden terhadap pertanyaan dalam media kuesioner berbentuk diukur dengan menggunakan skala Likert. Sugiyono (2018:93) menjelaskan skala Likert 
merupakan untuk mengukur sikap, pendapat dan persepsi seseorang atau sekelompok orang tentang fenomena sosial. Dalam Penelitian, fenomena sosial ini telah ditetapkan secara spesifik oleh peneliti, yang selanjutnya disebut sebagai variabel penelitian.

Variabel yang akan diukur dijabarkan menjadi indikator variabel. Kemudian indikator tersebut dijadikan sebagai titik tolak untuk menyusun item-item instrumen yang dapat berupa pernyataan atau pertanyaan. Jawaban dan pemberian skor dalam skala pengukuran dengan skala Likert adalah 1) sangat setuju dengan skor 5 2) setuju dengan skor 43 ) ragu-ragu dengan skor 34 ) tidak setuju dengan skor 2 dan 5) sangat tidak setuju dengan skor 1 (Sugiyono, 2018:93)

\section{Populasi dan Sampel}

Populasi dalam penelitian ini adalah seluruh karyawan tetap yang ada di PT. Sumatera Hakarindo Palembang sebanyak 40 orang. Teknik pengambilan sampel dalam penelitian ini menggunakan sensus sampling dimana seluruh anggota populasi menjadi anggota sampel.

\section{Sumber Data}

Data yang digunakan dalam penelitian ini adalah data primer. Sujarweni (2014:73) menjelaskan data Primer adalah data yang diperoleh dari responden melalui kuesioner, kelompok fokus, dan panel, atau juga data hasil wawancara peneliti dengan narasumber. Data yang diperoleh dari data primer ini harus diolah lagi.

\section{Teknik Pengumpulan Data}

Teknik pengumpulan data dalam penelitian ini adalah observasi, wawancara dan kuisioner. Observasi adalah dengan mengamati objek penelitian yaitu PT. Sumatera Hakarindo. Wawancara dilakukan kepada pihak yang ditunjuk PT.
Sumatera Hakarindo dalam memberikan data yang dibutuhkan dalam peneltitian. Kuisoner digunakan dalam mengumpulkan data penelitian dengan menyebarkan kuisioner yang berisikan pertanyaan untuk diberikan tanggapan oleh responden.

\section{Uji Instrumen Penelitian}

Uji instrumen dalam penelitian ini meliputi uji validitas dan uji reliabilitas. Validitas berarti sejauh mana ketepatan dan kecermatan suatu intrumen dalam melakukan fungsi ukurnya. Uji validitas mengunakan metode corrected item-total correlations dengan kriteria jika Sig $<\alpha$ $(0,05)$ maka dianggap instrumen memiliki validitas yang baik dan jika Sig >a $(0,05)$ maka dianggap instrumen tidak memiliki validitas yang baik.

Uji reliabilitas dimaksudkan untuk menguji konsistensi alat ukur. Uji reliabilitas pada penelitian ini mengunakan metode Cronbach's Alpha. Kriteria penerimaan adalah jika Cronbach's Alpha $>0,60$. Penyelesaian perhitungan uji validitas dan reliabilitas dalam peneltian ini menggunakan software SPSS for windows.

\section{Teknik Analisis Data}

Penelitian ini menggunakan teknik analisis data yaitu 1)regresi linear berganda yang didahului dengan uji asumsi klasik 2)koefisien determinasi dan 3)uji hipotesis baik uji simultan maupun uji parsial. Uji asumsi klasik meliputi 1)uji normalitas 2)uji multikolineariotas dan 3)uji heteroskedastistas. Penyelesain perhitungan pada teknik analisis data menggunakan software SPSS for windows.

Normalitas data merupakan hal yang penting karena dengan data yang terdistribusi normal, maka data tersebut dianggap dapat mewakili 
populasi. Uji normalitas dalam penelitian ini menggunakan analisis skewness dan kurtosis data. Pengambilan keputusan adalah jika nilai Z-skewness antara -1,96 dan +1,96 maka data mendekati simetris atau berdistribusi normal serta jika nilai Z-kurtosis antara -1,96 dan +1,96 berarti data memiliki keruncingan mesokurtik atau berdistribusi normal. Nilai-nilai tersebut diperoleh melalui pembagian nilai statistic dengan standar error baik skewness maupun kurtosis.

Uji muktikolinearitas diterapkan untuk menganalisa regresi berganda yang terdiri atas dua atau tiga variabel bebas dimana akan diukur tingkat asosiasi hubungan pengaruh antara variabel bebas tersebut dengan melihat nilai tolerance dan value inflation factor (VIF). Kriteria yang diterapkan adalah jika $\mathrm{VIF}>10$ atau jika tolerance $<0,01$ maka tidak terjadi multikolinieritas dan jjka $\mathrm{VIF}<10$ atau jika tolerance $>0,01$ maka terjadi multikolinieritas.

Uji heteroskedastisitas adalah keadaan dimana terjadi ketidaksamaan varian dari residu untuk pengamatan pada model regresi. Regresi yang baik seharusnya tidak terjadi heteroskedisitas. Deteksi ada tidaknya heteroskedisitas dapat dilakukan dengan uji Glejser. Cara mendeteksi ada tidaknya gejala heteroskedisitas adalah dengan cara melihat nilai signifikansi, apabila nilai sig $>0,05$ maka terjadi gejala heteroskedastisitas atau sebaliknya

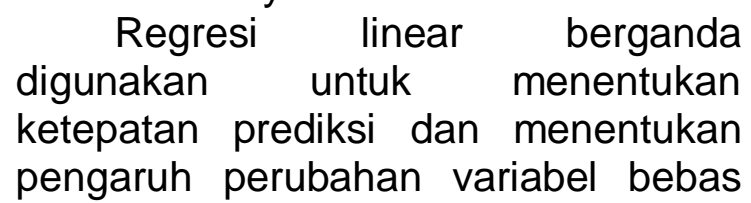

terhadap variabel terikat. Persamaan regresi yang digunakan adalah $\mathrm{Y}=\mathrm{a}+\mathrm{b}_{1} \mathrm{X}_{1}+\mathrm{b}_{2} \mathrm{X}_{2}$ dimana $\mathrm{Y}$ adalah variabel terikat semangat kerja, a adalah konstanta, $\mathrm{X}_{1}$ variabel bebas gaya kepemimpinan demokratis, $X_{2}$ adalah iklim kerja sedangkan $b_{1}$ adalah koefisien regresi dengan variabel bebas gaya kepemimpinan demokratis dan $b_{2}$ adalah koefisien regresi variabel bebas iklim kerja.

Koefisien determinasi adalah besaran yang menyatakan kontribusi variabel bebas terhadap variabel terikat. Kofisien determinasi juga menyatakan besaran kontribusi yang dinyatakan oleh variabel lain yang tidak dianalisis dalam model penelitian.

Uji simultan (uji F) digunakan untuk mengetahui apakah variabel bebas secara simultan berpengaruh terhadap variabel terikat. Kriteria penerimaan dan penolakan hipotesis adalah jika Sig<0,05, maka $\mathrm{H}_{\mathrm{o}}$ ditolak dan $\mathrm{H}_{\mathrm{a}}$ diterima dan jika Sig $>0,05$, maka $\mathrm{H}_{0}$ diterima dan $\mathrm{H}_{\mathrm{a}}$ ditolak. Uji parsial (uji t) digunakan untuk mengetahui apakah variabel bebas secara parsial berpengaruh terhadap variabel terikat Kriteria penerimaan dan penolakan hipotesis adalah jika Sig<0,05, maka $\mathrm{H}_{0}$ ditolak dan $\mathrm{H}_{\mathrm{a}}$ diterima dan jika Sig>0,05, maka $\mathrm{H}_{0}$ diterima dan $\mathrm{H}_{\mathrm{a}}$ ditolak.

\section{HASIL PENELITIAN Karakteristik Responden}

Karakteristik responden berdasarkan jenis kelamin, usia dan tingkat pendidikan. Kuisioner disebarkan kepada 40 responden. Tabel berikut ini menjelaskan karakteristik responden berdasarkan jenis kelamin. 


\begin{tabular}{|c|c|c|c|}
\hline No & Jenis Kelamin & Frekuensi & Persentase \\
\hline 1 & Laki-Laki & 34 & 85,00 \\
\hline 2 & Perempuan & 6 & 15,00 \\
\hline & Total & 40 & 100,00 \\
\hline
\end{tabular}

Sumber : Pengolahan Data 2019

Berdasarkan tabel di atas terlihat bahwa sebagian besar responden $(85,00 \%)$ berjenis kelamin laki-laki sedangkan perempuan sebesar $(15,00 \%)$. Dengan demikian dapat disimpulkan bahwa berdasarkan jenis kelamin karyawan pada PT. Sumatera Hakarindo Palembang yang dominan adalah jenis kelamin laki-laki.

Tabel berikut ini menjelaskan karakteristik responden berdasarkan usia.

\section{Karakteristik Karyawan Berdasarkan Usia}

\begin{tabular}{|c|c|c|c|}
\hline No & Usia & Frekuensi & Persentase \\
\hline 1 & $20-30$ & 28 & 70,00 \\
\hline 2 & $31-40$ & 12 & 30,00 \\
\hline \multicolumn{2}{|c|}{ Total } & 40 & 100,00 \\
\hline
\end{tabular}

Sumber : Pengolahan Data 2019

Berdasarkan tabel di atas terlihat sebanyak $70 \%$ responden berusia antara 20 sampai dengan 30 tahun, responden dengan usia 31 sampai dengan 40 tahun sebanyak $30,00 \%$. Dengan demikian dapat disimpulkan bahwa berdasarkan usia usia karyawan PT.Sumatera Hakarindo Palembang yang dominan adalah responden dengan usia 20 sampai dengan 30 tahun.

Tabel berikut ini menjelaskan karakteristik responden berdasarkan tingkat pendidikan.

Karakteristik Karyawan Berdasarkan Tingkat Pendidikan

\begin{tabular}{|c|c|c|c|}
\hline No & Pendidikan & Frekuensi & Persentase \\
\hline 1 & SMA & 14 & 35,00 \\
\hline 2 & D3 & 13 & 32,50 \\
\hline 3 & S1 & 13 & 32,50 \\
\hline & Total & 40 & 100,00 \\
\hline
\end{tabular}

Sumber : Pengelolahan Data 2019

Berdasarkan tabel di atas terlihat bahwa $35,00 \%$ berpendidikan SMA, sebanyak $32,50 \%$ responden berpendidikan D3 dan sebanyak $32,50 \%$ berpendidikan S1. Dengan demikian dapat disimpulkan bahwa berdasarkan tingkat pendidikan karyawan pada PT. Sumatera Hakarindo Palembang lebih banyak tamatan SMA.

\section{Uji Instrumen Penelitian}

Uji instrumen penelitian yang meliputi uji validitas dan uji realibilitas dilakukan kepada 40 responden dengan masing-masing 10 pertanyaan pada tiap variabel penelitian. Uji validitas dalam penelitian ini menggunakan metode corrected itemtotal correlations dengan kriteria penerimaan jika nilai sig $<\alpha(0,05)$ maka butir pernyataan dalam kuisioner dinyatakan valid. 
Hasil uji validitas dari variabelvariabel yang terlibat dalam penelitian diperlihatkan pada tabel berikut.

Uji Validitas

\begin{tabular}{|c|c|c|c|}
\hline \multirow{2}{*}{ Butir } & \multicolumn{3}{|c|}{ Sig } \\
\cline { 2 - 4 } & Gaya Kepemimpinan Demokratis & Iklim Kerja & Semangat Kerja \\
\hline 1 & 0,000 & 0,000 & 0,013 \\
\hline 2 & 0,000 & 0,000 & 0,000 \\
\hline 3 & 0,005 & 0,000 & 0,000 \\
\hline 4 & 0,000 & 0,000 & 0,001 \\
\hline 5 & 0,000 & 0,000 & 0,000 \\
\hline 6 & 0,000 & 0,000 & 0,000 \\
\hline 7 & 0,000 & 0,001 & 0,003 \\
\hline 8 & 0,001 & 0,002 & 0,000 \\
\hline 9 & 0,000 & 0,002 & 0,000 \\
\hline 10 & 0,000 & 0,000 & 0,000 \\
\hline
\end{tabular}

Sumber : Pengolahan Data 2019

Berdasarkan tabel diatas, semua butir pernyataan pada masing-masing variabel yang terlibat dalam penelitian menunjukkan nilai sig< $\alpha(0,05)$ berarti seluruh butir pernyataan dalam kuisioner dapat dikatakan valid. Dengan demikian butir-butir kuisioner variabel gaya kepemimpinan demokratis, iklim kerja dan semangat kerja sah untuk dijadikan instrumen dalam penelitian ini.

Uji reliabilitas dalam penelitian ini menggunakan metode Cronbach's Alpha dengan kriteria jika Cronbach's Alpha $>0,60$ maka butir kuisioner dinyatakan reliabilitas. Tabel berikut ini menjelaskan hasil uji reliabilitas variabel-variabel yang terlibat dalam penelitian.

Uji Reliabilitas

\begin{tabular}{|c|l|c|c|}
\hline No & \multicolumn{1}{|c|}{ Variabel } & Cronbach's Alpha & Keterangan \\
\hline 1 & Gaya Kepemimpinan Demokratis & 0,788 & Reliabel \\
\hline 2 & Iklim Kerja & 0,811 & Reliabel \\
\hline 3 & Semangat Kerja & 0,907 & Reliabel \\
\hline
\end{tabular}

Sumber : Pengolahan Data 2019

Berdasarkan tabel diatas, nilai Cronbach's Alpha variabel gaya kepemimpinan demokratis sebesar 0,788 , iklim kerja sebesar 0,811 , dan semangat kerja sebesar 0,907. Nilai reliabilitas semua variabel menunjukkan lebih dari 0,60 maka dapat dikatakan butir-butir kuisioner variabel gaya kepemimpinan demokratis, iklim kerja dan semangat kerja adalah reliabel .

\section{Uji Asumsi Klasik}

Uji asumsi klasik dalam penelitian ini meliputi uji normalitas, uji multikolinearitas dan uji heteroskedastisitas. Uji normalitas menggunakan analisis skewness dan kurtosis. Tabel berikut ini menjelaskan hasil uji normalitas.

\section{Uji Normalitas}




\begin{tabular}{|l|c|c|c|c|c|}
\hline \multirow{2}{*}{ Variabel } & \multicolumn{2}{c|}{ Skewness } & \multicolumn{2}{c|}{ Kurtosis } & Keterangan \\
\cline { 2 - 6 } & statistic & std.error & statistic & std.error & \\
\hline Gaya pemimpin demokratis & $-0,339$ & 0,374 & $-0,607$ & 0,733 & Normal \\
\hline Iklim kerja & $-0,549$ & 0,374 & 0,408 & 0,733 & Normal \\
\hline Semangat kerja & 0,031 & 0,374 & $-0,539$ & 0,733 & Normal \\
\hline
\end{tabular}

Sumber : Pengolahan data 2019

Berdasarkan tabel di atas, nilai Zskewness gaya kepemimpinan demokratis adalah $-0,906 \quad$ ($0,339 / 0,374)$ dan nilai Z-kurtosis adalah $-0,826(-0,607 / 0,734)$, nilai Zskewnes iklim kerja adalah -1,467 ($0,549 / 0,374)$ dan nilai Z-kurtosis adalah $-0,828(-0,607 / 0,733)$, nilai Zskewness semangat kerja adalah $0,828(0,31 / 0,374)$ dan nilai Z-kurtosis adalah $1,441(-0,539 / 0,733)$. Nilai Zskewness seluruh variabel penelitian berada antara $-1,96$ dan $+1,96$ maka data mendekati simetris serta nilai Zkurtosis seluruh variabel penelitian berada antara $-1,96$ dan $+1,96$ berarti data memiliki keruncingan mesokurtik. Dengan demikian distribusi data penelitian adalah normal.

Uji multikolinearitas menggunakan analisis nilai tolerance dan value inflation factor (VIF). Tabel berikut ini menjelaskan hasil uji multikolinearitas.

Uji Multikolinieritas

\begin{tabular}{|l|c|c|}
\hline \multicolumn{1}{|c|}{ Variabel } & Tolerance & VIF \\
\hline Gaya kepemimpinan demokratis & 0,997 & 1,003 \\
\hline Iklim Kerja & 0,997 & 1,003 \\
\hline
\end{tabular}

Sumber : Pengolahan Data 2019

Berdasarkan tabel di atas, nilai tolerance gaya kepemimpinan demokratis sebesar $0,997>0,10$ dan VIF $1,003<10$, sedangkan tolerance iklim kerja $0,997>0,10$ dan VIF $1,003<10$. Dengan demikian maka dapat disimpulkan tidak terjadi multikolinieritas.

$$
\text { Uji }
$$

heteroskedastisitas menggunakan uji Glejser. Tabel berikut ini menjelaskan hasil uji heteroskedastisitas

\section{Uji Heteroskedastisitas}

\begin{tabular}{|l|c|c|c|}
\hline \multicolumn{1}{|c|}{ Variabel } & Signifikan & $\alpha$ & Keterangan \\
\hline Gaya kepemimpinan demokratis & 0,170 & 0,05 & Tidak terjadi Heteroskedastisitas \\
\hline Iklim Kerja & 0,892 & 0,05 & Tidak terjadi Heteroskedastisitas \\
\hline
\end{tabular}

Sumber : Pengolahan Data 2019

Berdasarkan tabel di atas, nilai signifikansi dari variabel-variabel bebas lebih besar dari 0,05 (sig > $0,05)$ Dengan demikian bahwa dalam model regresi yang digunakan tidak terjadi heteroskedastisitas.

Regresi Linear Berganda
Setelah prasyarat untuk melakukan analisis regresi linear berganda dipenuhi melalui uji asumsi klasik, selanjutnya dapat dibentuk persamaan regresi berganda. Tabel berikut ini menjelaskan hasil regresi linear berganda. 


\begin{tabular}{|c|c|c|c|c|c|c|}
\hline \multirow{2}{*}{\multicolumn{2}{|c|}{ Model }} & \multicolumn{2}{|c|}{$\begin{array}{c}\text { Unstandardized } \\
\text { Coefficients }\end{array}$} & \multirow{2}{*}{$\begin{array}{c}\text { Standardized } \\
\text { Coefficients } \\
\text { Beta }\end{array}$} & \multirow[b]{2}{*}{$\mathrm{t}$} & \multirow[b]{2}{*}{ Sig. } \\
\hline & & $\mathrm{B}$ & Std. Error & & & \\
\hline \multirow[t]{3}{*}{1} & (Constant) & 17,685 & 7,685 & & 2,301 & ,027 \\
\hline & Gaya Kepemimpinan Demokratis & ,253 &, 104 & ,348 & 2,439 &, 020 \\
\hline & Iklim Kerja & ,373 & , 159 & ,336 & 2,352 & ,024 \\
\hline
\end{tabular}

a. Dependent Variable: Semangat Kerja

Sumber : Pengolahan Data 2019

Berdasarkan tabel diatas, diperoleh persamaan regresi linier berganda $Y=17,685+0,253 X_{1}+0,373 X_{2}$ dimana nilai konstanta a sebesar 17,685 , koefisien regresi $b_{1}$ sebesar 0,253 dan koefisien regresi $b_{2}$ sebesar 0,373 .

\section{Koefisien Determinasi}

Koefisien determinasi dianalisis untuk mendukung pengaruh perubahan variabel bebas terhadap variabel terikat melalui besaran kontribusi variabel bebas terhadap variabel terikat. Tabel berikut ini menjelaskan nilai koefisien determinasi.

Model Summary

\begin{tabular}{|c|r|r|r|r|}
\hline Model & $\mathrm{R}$ & R Square & Adjusted R Square & Std. Error of the Estimate \\
\hline 1 &, $497^{\mathrm{a}}$ &, 247 &, 206 & 3,74260 \\
\hline
\end{tabular}

a. Predictors: (Constant), Iklim Kerja, Gaya kepemimpinan Demokratis

b. Dependent Variable: Semangat Kerja

Sumber : Pengolahan Data 2019

Berdasarkan tabel di atas, diperoleh nilai koefisien determinasi $(R$ Square) sebesar 0,247 atau $24,7 \%$.

\section{Pengujian Hipotesis}

Pengujian hipotesis meliputi uji $F$ dan uji t dengan variabel bebas gaya kepemimpinan dan iklim kerja serta variabel terikat semangat kerja. Tabel berikut ini menjelaskan hasil pengujian hipotesis dengan uji simultan (uji F).

ANOVA $^{\mathrm{a}}$

\begin{tabular}{|c|c|c|c|c|c|c|}
\hline & Model & Sum of Squares & Df & Mean Square & $\mathrm{F}$ & Sig. \\
\hline \multirow[t]{3}{*}{1} & Regression & 170,115 & 2 & 85,057 & 6,072 &, $005^{b}$ \\
\hline & Residual & 518,260 & 37 & 14,007 & & \\
\hline & Total & 688,375 & 39 & & & \\
\hline
\end{tabular}

a. Dependent Variable: Semangat Kerja

b. Predictors: (Constant), Iklim Kerja, Gaya kepemimpinan Demokratis

Sumber : Pengolahan Data 2019

Berdasarkan tabel diatas, diperoleh nilai sig sebesar 0,005 atau $0,005<\alpha(0,05)$ sehingga hipotesis nol ditolak dan hipotesis alternatif diterima. 
Tabel berikut ini menjelaskan hasil uji hipotesis dengan uji parsial (uji t) masing-masing variabel penelitian.

\begin{tabular}{|c|c|c|c|c|c|c|}
\hline \multirow{2}{*}{\multicolumn{2}{|c|}{ Model }} & \multicolumn{2}{|c|}{$\begin{array}{c}\text { Unstandardized } \\
\text { Coefficients } \\
\end{array}$} & \multirow{2}{*}{$\begin{array}{c}\begin{array}{c}\text { Standardized } \\
\text { Coefficients }\end{array} \\
\text { Beta }\end{array}$} & \multirow[b]{2}{*}{$t$} & \multirow[b]{2}{*}{ Sig. } \\
\hline & & $\mathrm{B}$ & Std. Error & & & \\
\hline \multirow[t]{3}{*}{1} & (Constant) & 17,685 & 7,685 & & 2,301 & ,027 \\
\hline & Gaya Kepemimpinan Demokratis & ,253 & ,104 & ,348 & 2,439 & ,020 \\
\hline & Iklim Kerja & ,373 & 159 & ,336 & 2,352 & ,024 \\
\hline
\end{tabular}

Dependent Variable: Semangat Kerja

Sumber : Pengolahan Data 2019

Berdasarkan tabel di atas, uji parsial dengan variabel bebas gaya kepemimpinan demokratis diperoleh nilai sig sebesar 0,020 atau $0,020<\alpha$ $(0,05)$ sehingga hipotesis nol ditolak dan hipotesis alternatif diterima, uji parsial dengan variabel bebas iklim kerja diperoleh nilai sig sebesar 0,24 atau $0,24<\alpha(0,05)$ sehingga hipotesis nol ditolak dan hipotesis alternatif diterima.

\section{E. PEMBAHASAN}

Analisis regresi linear berganda menunjukkan pengaruh perubahan variabel bebas terhadap variabel terikat. Persamaan regresi linier berganda $Y=17,685+0,253 X_{1}+0,373 X_{2}$ menunjukkan nilai konstanta a sebesar 17,685 yang berarti jika pemimpin tidak memiliki gaya kepemimpinan demokratis dan tidak ada iklim kerja yang tertata, semangat kerja karayawan sebesar 17,685 satuan. Koefisien regresi $b_{1}$ dengan variabel gaya kepemimpinan demokratis sebesar 0,253 menunjukkan jika semakin luas penggunaan gaya kepemimpinan demokratis maka semakin tinggi semangat kerja karyawan dan sebaliknya jika semakin terbatas penggunaan gaya kepemimpinan demokratis maka semakin rendah semangat kerja karyawan dimana variabel iklim kerja konstan. Koefisien regresi $b_{2}$ sebesar 0,373 menunjukkan jika semakin baik iklim kerja maka semakin tinggi semangat kerja karyawan dan sebaliknya semakin kurang baik iklim kerja maka semakin rendah semangat kerja karyawan dimana variabel gaya kepemimpinan konstan.

Analisis koefisien determinasi ( $R$ Square) menunjukkan besarnya kontribusi variabel bebas terhadap variabel terikat. Koefisien determinasi sebesar 24,7\% menunjukkan kontribusi gaya kepemimpinan demokratis dan iklim kerja terhadap semangat kerja karyawan PT. Sumatera Hakarindo sedangkan $75,3 \%$ dikontribusikan oleh variabel lain yang tidak diteliti dalam model regresi. Variabel tersebut diantaranya gaji atau upah, pengawasan dan lainlain.

Pengujian hipotesis dengan uji simultan (uji F) menghasilkan nilai sig sebesar 0,005 atau $0,005<\alpha \quad(0,05)$ sehingga hipotesis nol ditolak dan hipotesis alternatif diterima. Penerimaan hipotesis alternatif berarti secara simultan, gaya kepemimpinan demokratis dan iklim kerja berpengaruh signifikan terhadap semangat kerja karyawan pada PT. Sumatera Hakarindo Palembang 
Pengujian hipotesis melalui uji parsial (uji t) dengan variabel bebas gaya kepemimpinan demokratis menghasilkan nilai sig sebesar 0,005 atau $0,005<\alpha(0,05)$ sehingga hipotesis nol ditolak dan hipotesis alternatif diterima. Penerimaan hipotesis alternatif berarti secara parsial, gaya kepemimpinan demokratis berpengaruh signifikan terhadap semangat kerja karyawan pada PT. Sumatera Hakarindo Palembang. Pengujian hipotesis melalui uji parsial (uji t) dengan variabel bebas iklim kerja menghasilkan nilai sig sebesar 0,005 atau $0,005<\alpha(0,05)$ sehingga hipotesis nol ditolak dan hipotesis alternatif diterima. Penerimaan hipotesis alternatif berarti secara parsial, iklim kerja berpengaruh signifikan terhadap semangat kerja karyawan pada PT. Sumatera Hakarindo Palembang.

\section{F. KESIMPULAN DAN SARAN}

\section{1) Kesimpulan}

Pengujian hipotesis dengan uji $\mathrm{F}$ menghasilkan penerimaan hipotesis alternatif yang berarti secara simultan, gaya kepemimpinan demokratis dan iklim kerja berpengaruh signifikan terhadap semangat kerja karyawan pada PT. Sumatera Hakarindo Palembang. Pengujian hipotesis melalui uji $\mathrm{t}$ dengan variabel bebas gaya kepemimpinan demokratis menghasilkan penerimaan hipotesis alternatif berarti secara parsial, gaya kepemimpinan demokratis berpengaruh signifikan terhadap semangat kerja karyawan pada PT. Sumatera Hakarindo Palembang sedangkan uji t dengan variabel bebas iklim kerja menghasilkan penerimaan hipotesis alternatif berarti secara parsial, iklim kerja berpengaruh signifikan terhadap semangat kerja karyawan pada PT. Sumatera Hakarindo Palembang.

\section{2) Saran}

Saran yang diharapkan dapat menjadi bahan masukan bagi PT. Sumatera Hakarido Palembang adalah 1)diharapkan dengan gaya kepemimpinan demokratis dapat menciptakan semangat kerja karyawan 2)diharapkan dapat meningkatkan iklim kerja yang baik sehingga karyawan merasakan semangat kerja untuk mencapai tujuan perusahaan dan 3)sebaiknya pihak manajemen perusahaan meningkatkan pengelolaan sumber daya manusia yang dimiliki agar semangat kerja karyawan meningkat.

\section{DAFTAR PUSTAKA}

Busro, Muhammad. 2018. Teori-Teori Manajemen Sumberdaya Manusia. Jakarta:Prenada Media Group.

Rahsel, Yoeyong. 2016. Pengaruh Iklim Kerja Terhadap Kinerja Pegawai Administrasi Pusat Universitas Padjadjaran Bandung.Jurnal Manajemen Magister UNPAD Volume 02 Nomor 1

Rivai dan Mulyadi. 2011. Kepemimpinan dan Prilaku Organisasi. Jakarta:PT. Rajagrafindo Persada.

Sedarmayanti. 2011.Membangun Dan Mengembangkan Kepemimpinan Serta Meningkatkan Kinerja Untuk Meraih Keberhasilan. Bandung:PT. Refika Aditama.

Senang dan Masclahah. 2018. Kepemimpinan dan Supervisi Pendidikan Islam. Malang:Madani. 
Sugiyono. 2018. Metode Penelitian Kuantitatif, Kualitatif, $R$ \& $D$. Bandung:Alfabeta.

Sujarweni. 2014. Metode Penelitian. Yogyakarta:Putaka Baru Pres.

Suryalena dan Multi R.P. 2013. Pengaruh Iklim Kerja Terhadap
Semangat kerja Karyawan Bagian Produksi pada PT. Asia Sawit Makmur Jaya, Kabupaten Kuantan Singingi, Riau. Jurnal Aplikasi Bisnis volume 4 nomor 1.

Thoha, Miftah. 2010. Kepemimpinan Dan Manajemen. Jakarta:PT Rajagrafindo

Persada. 